\title{
Stress and Stressors of Penitentiary Workers in the State of Bahia, Brazil
}

\section{José Gomes $S^{*}$}

Department of Faculty Piodécimo, Brazil

*Corresponding author: Sandro José Gomes, Associate Professor of the Faculdade Piodécimo, Director of Penitentiary Unit in the State of Bahia, Brazil, Email: sandro.gomes@seap.ba.gov.br

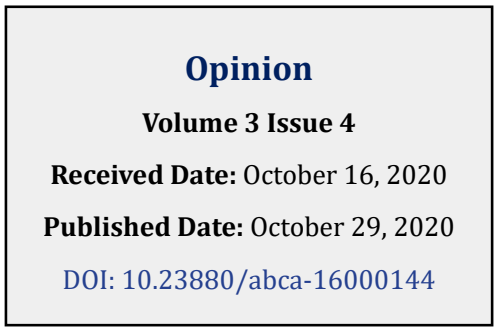

\section{Investigation Paper}

This paper presents the results of the research carried out in the elaboration of the Doctoral Thesis in Psychology entitled "Leadership in Unstable Contexts: Stress and Stressors of Prison Managers and Prison Agents in Prison Units in the State of Bahia", defended and approved in 2016 at the Autonomous University from Lisbon, in Portugal.

The objectives of this study was to analyze the relationship between stressors, coping, stress symptoms and leadership style and their implications for managerial activity in prison units in Bahia; describing the correspondence of these relations with the main propositions of the Cognitive Resource Theory by Fiedler and his collaborators.

The hypotheses were raised considering that the negative effects of stress and inappropriate leadership style have implications for managerial activity. The research was correlational and descriptive, within quantitative analyzes, carried out based on an exhaustive bibliographic survey on the theme, portrayed in the literature review, and theoretical foundation, on two approaches: psychological issues and control over work in the prison environment Bahi, et al. [1]; Bonez A, et al. [2]; Lambert EG, et al. [3]; Molleman T, et al. [4] and the influence of stress on leadership $[5,6]$.

The research had, in the concrete plan of the investigation, the application of the Vulnerability to Stress at Work Scale built by Sisto FF, et al. [7], of the Inventory of Symptoms of Stress built by Lipp MN, et al. [8], and the Toulousaine de Coping Scale adapted from Esparbès, SordesArder and Tap by Stephenson MIGP, et al. [9] for use with the Brazilian population, in addition to the Management Styles Assessment Scale created by Melo EAA, et al. [10] and a brief occupational questionnaire. Which was applied for the purpose of facilitating the understanding of the Management Styles Assessment Scale?.
As for the study population, it consisted of 1600 prison officers and 100 prison managers, involving all prison managers and all prison officers in the prison units in Bahia, with the study sample consisting of 320 prison officers and 80 prison managers. A high level of stress was found in the population studied, making it evident that the variable EVENT Pressure at Work has a significant effect on ETC $(B=0.095 ; p=0.003)$, indicating that the increase in pressure at work causes an increase in the use of coping strategies.

A strong and significant positive correlation was also found between Refusal and Isolation ( $\mathrm{r}=.769 ; \mathrm{p}<.01)$, indicating that high levels of refusal are associated with high levels of isolation, with Control being negatively correlated with Isolation $(\mathrm{r}=-.642 ; \mathrm{p}<.01)$ and with Refusal $(\mathrm{r}=-.623$; $\mathrm{p}<.01$ ). Thus, abusive use of isolation strategies was found in the ETC and in the ISSL a high number of individuals in the most advanced stages of stress, being diagnosed that among prison officers $70 \%(n=224)$ regularly consume alcohol or other drugs and $39.38 \%(n=126)$ are in the near-exhaustion or exhaustion phase and among prison managers $40 \%$ $(n=32)$ consume alcohol or other drugs regularly and $27.5 \%$ $(n=22)$ are in the near-exhaustion phase or exhaustion.

The survey also showed that the more the manager is focused on the tasks, the less he values his relationship with prison officers $(\mathrm{r}=-.186 ; \mathrm{p}<.05)$, with a positive correlation of the leadership style focused on the tasks $(\mathrm{r}=.112 ; \mathrm{p}<.05)$ with symptoms of stress.

In view of the results found in the hypotheses, it was evident that the relationship between leadership style and stress affects the management activity to the point that the tasks are not performed satisfactorily, even in the units that had experienced managers and endowed with specialized knowledge. The results were discussed with a partial 
correspondence of the correlation between stress and leadership style with Cognitive Resource Theory.

Again, the study showed that the effectiveness of the prison manager under a condition of high stress does not consist of his experience, according to what the Cognitive Resource Theory of Fiedler and his collaborators defends; however, in developing networks of relationships that help you decide in such circumstances.

\section{References}

1. Bahia (2014) Bahia and its prison system: Challenges and advances. Poster presented at Worshop Management by Process in the Prison System of Bahia held at the Secretariat of Penitentiary Administration and Resocialization, Salvador.

2. Bonez A, Dal Moro E, Sehnem SB (2013) Mental health of prison officers in a Santa Catarina prison. Psychology Argument 31(74): 507-517.

3. Lambert EG, Barton-Bellessa SM, Hogan NL (2014) The association between correctional orientation and organizational citizenship behaviors among correctional staff. Int J Offender Ther Comp Criminol 58(8): 953-974.

4. Molleman T, Van der Broek TC (2014) Understanding the links between perceived prison conditions and prison staff. International Journal of Law, Crime and Justice 42(1): 33-53.

5. Atkin-Plunk CA, Armstrong GS (2013) Transformational leadership skills and correlates of prison warden job stress. Criminal Justice and Behavior 40(5): 551-568.

6. Fiedler FE, Garcia JE (1987) New approaches to effective leadership: Cognitive resources and organizational performance. The Academy of Management Review 13(2): 328-330.

7. Sisto FF, Baptista MN, Noronha AP, Santos AAA (2007) Scale of vulnerability to stress at work - EVENT. São Paulo: Vetor Editora.

8. Lipp MN (2000 a) Inventory of symptoms of stress for lipp adults (ISSL). Sao Paulo: Psychologist's House.

9. Stephenson MIGP (2001) Tress: Coping strategies and social representations of the disease among HIV positive people in Brazil (Tese de douboramento não publicada). University of Tolouse, Tolouse.

10. Melo EAA (2004) Management style assessment scale (EAEG): Development and validation. Revista Psicologia: Organizations and Work 4(2): 31-62.

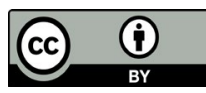

